УДК 37.09

DOI:

Андрій Григорович, кандидат технічних наук, заступник директора Дрогобицького ліщею Ольга Заяць, кандидат педагогічних наук, доцент, директор Дрогобиџького ліџею Мар'яна Гладкевич, старший викладач кафедри теоретичної та консультативної психології факультету сочіально-психологічних наук та управління Національно педагогічного університету імені М.П. Драгоманова, м. Київ

\title{
КОМПЕТЕНТНІСНО ЗОРІСНТОВАНІ ПЕДАГОГІЧНІ ТЕХНОЛОГІЇ ЯК ФАКТОР ЗАБЕЗПЕЧЕННЯ ЯКОСТІ ОСВІТИ У ДРОГОБИЦЬКОМУ ЛІЦЕЇ
}

У статті описано систему педагогічних технологій, розроблених та впроваджених у Дрогобицькому лічеї, спрямовану на формування компетентного випускника. Наведено ключові компетентності, якими повинен володіти випускник иколи. Проаналізовано вплив освітніх технологій на формування ключових компетентностей. Обтрунтовано ефективність використання описаної системи педагогічних технологій з метою забезпечення якості освіти.

Ключові слова: педагогічні технологї̈; компетентність; ліцей; якість освіти.

Табл. 3. Лім. 15.

Andriy Hryhorovych, Ph.D.(Technical Science), Vice Director of the Drohobych Lyceum Olha Zayets, Ph.D.(Pedagogy), Associate Professor, Director of the Drohobych Lyceum Maryana Hladkevych, Senior Lecturer of the Theoretical and Consultative Psychology Department, Faculty of Social and Psychological Sciences and Management National Mykhaylo Drahomanov Pedagogical University, Kyiv

\section{COMPETENCE-ORIENTED PEDAGOGICAL TECHNOLOGIES AS A FACTOR PROVIDING QUALITY OF EDUCATION IN DROHOBYCH LYCEUM}

The problem of systematic use of pedagogical technologies in Drohobych Lyceum with the purpose of forming the key competences of the graduate of the senior profile school was solved in the article. The key competences that young Europeans must possess in accordance with the Council of Europe's demand and the competences defined by the Law of Ukraine "On Education" are analyzed. The common components for all of these competencies are defined: knowledge, not just information; ability to use this knowledge to solve applied problems; ability to assess yourself and your knowledge adequately. The educational technologies implemented in Lyceum are described: the students 'self-government; summer vacation; subject tournaments; brain ring; quests; projects; foreign study trips of schoolchildren; internship of students; a week of foreign languages; a system of educational work; receiving of students from the eastern regions of Ukraine and from abroad; presentation of creative tasks; educational and pedagogical practice; participation in student conferences; English camps and clubs; political information; modular rating system for assessing the students' knowledge; a system of preparation for external evaluation; semester control works; the exam after the first year; organization of preparatory courses for entrants of the lyceum. The influence of the system of pedagogical technologies introduced in the Lyceum on the formation of key competences of the graduate student has been determined. On the basis of the analysis of the results of the external independent evaluation and the activity of the scientific society of the Drohobych Lyceum, the conclusion is drawn about the effectiveness of the system of pedagogical technologies developed and implemented in the Lyceum practice that form and develop the key competences of senior pupils.

Keywords: pedagogical technologies; competence; lyceum; a quality of education; an educational process.

П остановка проблеми. Одним із актуальних завдань, які стоять перед українською освітою на етапі іiі реформування, $\epsilon$ перехід від знаннєвої парадигми до компетентнісної. "Національна стратегія розвитку освіти на період до 2021 року” одним 3 ключових напрямів Державної освітньої політики називає модернізацію структури, змісту й організації освіти на засадах компетентнісного підходу. Сьогодні головне завдання школи - не вчити, а навчати вчитися, підготувати учня до неперервного навчання. Тому мають змінитися функції учня і функції учителя. Перший повинен буде разом із засвоєнням відповідних знань розвивати в собі здатність, навички, уміння самостійно їх шукати, тобто оволодівати науковим методом пізнання. Другий же відповідно допомогти першому навчитися вчитись.

Аналіз основних досліджень. Дослідження аспектів ключових компетентностей грунтовно висвітлено в роботах П. Горностая, В. Донія, I. Єрмакова, І. Зимньої, В. Ляшенка, Г. Несен, 


\section{КОМПЕТЕНТНІСНО ЗОРІЕНТОВАНІПЕДАГОГІЧНІ ТЕХНОЛОГЇ ЯК ФАКТОР ЗАБЕЗПЕЧЕННЯ ЯКОСТІ ОСВІТИ У ДРОГОБИЦЬКОМУ ЛІЦЕЇ}

О. Овчарук, Л. Соханя та ін. Проте проблема системного використання педагогічних технологій 3 метою формування ключових компетентностей у старшій профільній школі залишається до цього часу не вивченою. Зазначене вище обгрунтовує актуальність і перспективність визначеного напрямку дослідження та зумовило формулювання мети статті: описати систему педагогічних технологій, розроблених та впроваджених у Дрогобицькому ліцеї, спрямовану на формування компетентного випускника та обгрунтувати іï ефективність як фактора забезпечення якості освіти.

Виклад основного матеріалу. Рада Свропи сформулювала [1] п’ять ключових компетентностей, якими повинні володіти молоді європейці:

1) політичні й соціальні компетенції-здатність приймати відповідальність, брати участь у прийнятті групових рішень, розв'язувати конфлікти мирно, брати участь у підтримці й поліпшенні демократичних інститутів;

2) компетенції, пов'язані 3 життям у багатокультурному суспільстві. Щоб контролювати виявлення (відродження) расизму та ксенофобії, клімат нетолерантності, освіта має “озброїти” молодих людей міжкультурними компетенціями: прийняття відмінностей, повага до інших і здатність жити з людьми інших культур, мов і релігій;

3) компетенції, що передбачають володіння (mastery) усною та письмовою комунікацією, які особливо важливі для роботи й соціального життя, 3 акцентом на тому, що людям, які не володіють ними, загрожує соціальна ізоляція. У цьому контексті комунікації дедалі важливішим стає володіння більш ніж однією мовою;

4) компетенції, пов'язані зі стрімкою інформатизацією суспільства. Володіння технологіями, розуміння їх застосування, слабких і сильних сторін та способів критичного судження стосовно інформації, поширюваної мас-медійними засобами та рекламою;

5) здатність навчатися протягом життя як основа неперервного навчання в контексті особистого, професійного та соціального життя.

Закон України “Про освіту” [11] наводить таке визначення: “компетентність - динамічна комбінація знань, умінь, навичок, способів мислення, поглядів, цінностей, інших особистих якостей, що визначає здатність особи успішно соціалізуватися, провадити професійну та/або подальшу навчальну діяльність”. Там же визначено ключові компетентності, які повинні бути сформовані за час здобуття повної середньої освіти і які необхідні кожній сучасній людині для успішної життедіяльності:

- вільне володіння державною мовою;

- здатність спілкуватися рідною (у разі відмінності від державної) та іноземними мовами;

- математична компетентність;

- компетентності у галузі природничих наук, техніки і технологій;

- інноваційність;

- екологічна компетентність;

- інформаційно-комунікаційна компетентність; навчання впродовж життя;

- громадянські та соціальні компетентності, пов'язані з ідеями демократії, справедливості, рівності, прав людини, добробуту та здорового способу життя, $з$ усвідомленням рівних прав і можливостей;

- культурна компетентність;

- підприємливість та фінансова грамотність;

- інші компетентності, передбачені стандартом освіти.

Можна виділити три спільні складові для всіх цих компетентностей: знання, а не просто інформація; вміння застосовувати ці знання для вирішення прикладних завдань; уміння адекватно оцінювати себе та свої знання. I саме на формування цих компетенностей повинні бути спрямовані педагогічні технології, які застосовуються в освітньому процесі.

Дрогобицький ліцей Дрогобицької міської ради Львівської області при Дрогобицькому державному педагогічному університеті імені Івана Франка - заклад загальної середньої освіти (33СО), який здійснює профільне навчання старшокласників за чотирма профілями: гуманітарному, природничому, правничому, інформаційних технологій. Термін навчання у ліцеї - два роки, що відповідає 10 та 11 класам 33СО. Взаємозв'язок впровадженої в ліцеї [10] системи педагогічних технологій 3 ключовими компетентностями відображено в таблиці 1.

Опишемо деякі з цих технологій детальніше.

Науково-пошукова діяльність учнів відіграє велике значення у розвитку їх інтелектуальних здібностей та у процесі підготовки старшокласників до продовження навчання у вищих навчальних закладах. Адже саме у самостійній дослідницькій роботі формуються творчі навички й компетенції, які необхідні для успішного навчання у вишах.

Наукове товариство Дрогобицького ліцею (НТ) створене 25 грудня 2010 року і функціонує з метою координації організаційного та науковометодичного забезпечення роботи з обдарованою молоддю, створення сприятливих умов для розвитку і реалізації творчих та інтелектуальних 
Вплив освітніх технологій на формування ключових компетентностей

Таблиця 1.

\begin{tabular}{|c|c|}
\hline Компетентності & Технології \\
\hline Політичні й соціальні компетенції & $\begin{array}{l}\text { Учнівське самоврядування; } \\
\text { Літня практика [5]; } \\
\text { Літній відпочинок; } \\
\text { Предметні турніри; } \\
\text { Брейн-ринг; } \\
\text { Квести [9]; } \\
\text { Проекти [12, 14]. }\end{array}$ \\
\hline $\begin{array}{l}\text { Компетенції, пов’язані з життям у } \\
\text { багатокультурному суспільстві }\end{array}$ & $\begin{array}{l}\text { Закордонні краєзнавчі поїздки учнів; } \\
\text { Стажування учнів; } \\
\text { Тиждень іноземних мов; } \\
\text { Система виховної роботи; } \\
\text { Прийом учнів зі східних областей та 3-за кордону. }\end{array}$ \\
\hline $\begin{array}{l}\text { Компетенції, що передбачають володіння } \\
\text { усною та письмовою комунікацією }\end{array}$ & $\begin{array}{l}\text { Захист творчих завдань [15]; } \\
\text { Навчальна і педагогічна практики [5]; } \\
\text { Предметні турніри; } \\
\text { Виступи на учнівських конференціях [4]; } \\
\text { Англомовні табори, клуби; } \\
\text { Вивчення трьох іноземних мов у гуманітарному } \\
\text { профілі; } \\
\text { Закордонні краєзнавчі поїздки учнів; } \\
\text { Стажування учнів. }\end{array}$ \\
\hline $\begin{array}{l}\text { Компетенції, пов’язані зі стрімкою } \\
\text { інформатизацією суспільства }\end{array}$ & $\begin{array}{l}\text { Творчі завдання [15]; } \\
\text { Навчальні проекти }[8,12] \\
\text { Політінформації. }\end{array}$ \\
\hline Здатність навчатися протягом життя & $\begin{array}{l}\text { Модульно-рейтингова система оцінювання знань [2]; } \\
\text { Системна підготовка до ЗНО; } \\
\text { Семестрові контрольні роботи; } \\
\text { Екзамен після I курсу [3]; } \\
\text { Підготовчі курси. }\end{array}$ \\
\hline
\end{tabular}

здібностей ліцеїстів, залучення ліцеїстів і вчителів ліцею до науково-дослідницької та іншої творчої діяльності в процесі навчання, участі у вирішенні актуальних наукових проблем [6; 7; 13].

Передумовами створення Наукового товариства була активна робота педагогічного колективу ліцею по залученню ліцеїстів до науковопошукової роботи та розвитку їх творчих здібностей, зокрема:

- творчі роботи учнів (впроваджені в ліцеї 3 1991 p.);

- проектна діяльність під час навчальної, фольклорної та педагогічної практик;

- участь у міжнародних та Всеукраїнських змаганнях (Міжнародний турнір міст $з$ фізики, Галицькі турніри юних інформатиків тощо);

- організація всеукраїнських інтелектуальних змагань (математичний фестиваль імені проф. Чайківського, Всеукраїнські фізико-математичні $(2006,2008,2010)$ та економічні $(2007,2009)$ фестивалі, обласна очно-заочна олімпіада (20022010).

Важливим фактором, який впливає на якість та ефективність роботи наукового товариства ліцеїстів $€$ активна науково-дослідницька діяльність вчителів. Педагогічний колектив ліцею налічує 36 вчителів, 25 я яких мають вищу кваліфікаційну категорію, 3 - першу, 4 - другу. Восьмеро педагогів мають звання "учительметодист”, дванадцятеро - “старший учитель”, семеро - “Відмінник освіти України”. Серед учителів ліцею один Заслужений учитель України, два кандидати наук, один доцент. Дрогобицький ліцей функціонує у комплексі з Дрогобицьким державним педагогічним університетом імені Івана Франка. Вчителі ліцею залучаються до наукових досліджень університету. У творчому доробку педагогічного колективу ліцею понад 270 наукових та навчально-методичних публікацій. За останні п’ять років учителі ліцею брали участь у роботі 29 наукових конференцій.

У науковому товаристві Дрогобицького ліцею запроваджені такі форми роботи з інтелектуально обдарованими дітьми:

- організація та проведення щорічної звітної науково-практичної конференції ліцеїстів;

- участь у конкурсі-захисті науководослідницьких робіт МАН; 
КОМПЕТЕНТНІСНОЗОРІЄНТОВАНІПЕДАГОГІЧНІ ТЕХНОЛОГЇ̈ ЯК ФАКТОР ЗАБЕЗПЕЧЕННЯ ЯКОСТІ ОСВІТИ У ДРОГОБИЦЬКОМУ ЛІЩЁ̈ - участь у Всеукраїнських предметних
турнірах;
- педагогічної практики;
- організація та проведення обласного
чемпіонатуз брейн-рингу;
- участь в інтелектуальних конкурсах та
змаганнях; ліцею.

- публікація друкованих видань Дрогобицького

3 метою розвитку пізнавальних інтересів і творчості учнів, залучення до наукового пошуку, розширення світогляду, набуття навичок самостійної роботи та науково-дослідницької діяльності, професійного самовизначення й ранньої професійної орієнтації проводиться щорічна звітна науково-практична конференція ліцеїстів. До участі в конференції допускаються ліцеїсти I - II курсів. Результати звітної науково-практичної конференції зараховуються як результати I етапу Всеукраїнських конкурсів-захистів науководослідницьких робіт членів МАН. Кращі роботи подаються на II етап. Робота конференції організована відповідно переліку наукових відділень і секцій Малої академії наук України, в яких проводиться III етап Всеукраїнського конкурсу-захисту науково-дослідницьких робіт учнів-членів МАН.

Написання творчих робіт і підготовка до конференції розпочинається увересні й здійснюється за затвердженим планом, який передбачає:

1. Формулювання тем творчих робіт. Кожен вчитель формулює по десять тем, при цьому увага звертається на пошуково-практичну спрямованість робіт.

2. Затвердження тем на засіданнях кафедр ліцею (природничих, гуманітарних наук, іноземних мов та виховної роботи).

3. Обрання тем ліцеїстами. Обрані теми затверджуються наказом директора ліцею.
4. Написання робіт.

5. Попередній захист робіт на кафедрах.

6. Розгляд та рекомендації до друку тез доповідей на засіданні кафедр.

7. Випуск збірника тез доповідей.

8. Проведення пленарного та секційних засідань конференції.

9. Підведення підсумків проведення конференції на засіданнях кафедр.

Методичні рекомендації ліцеїстам по написанню та оформленню творчих робіт, анотацій та тез доповідей публікуються у щомісячному виданні Дрогобицького ліцею - газеті “Ліцеїст" та на сайті ліцею. До початку конференції видається ії програма та Збірник тез доповідей звітної науково-практичної конференції ліцеїстів.

Робота конференції відбувається на пленарному та секційному засіданнях. Необхідно зазначити, що до керування творчими роботами ліцеїстів залучається професорсько-викладацький склад Дрогобицького державного педагогічного університету імені Івана Франка, науковці Львівського національного університету імені Івана Франка, Інституту фізики конденсованих систем НАН України тощо.

Результативність участі наукового товариства ліцею у конкурсі-захисті науково-дослідницьких робіт МАН відображено у таблиці 2. Протягом останніх років наукове товариство ліцею займає перше місце у рейтингу міських та районних наукових товариств МАН Львівської області.

Командною формою змагань, які організовує Мала академія наук України і в яких бере участь Наукове товариство ліцею, є предметні турніри. Результати участі ліцеїстів у цих змаганнях відображені в таблиці 3. На жаль, відсутність фінансування є вагомим фактором, який обмежує участь у всеукраїнському етапі цих змагань.

Таблиця 2.

Результативність участі ліцеїстів у II та III етапах Всеукраїнського конкурсу-захисту науково-дослідницьких робіт МАН

\begin{tabular}{|c|c|c|}
\hline Навчальний рік & $\begin{array}{c}\text { Кількість перемог } \\
\text { у II (обласному) етап }\end{array}$ & $\begin{array}{c}\text { Кількість перемог } \\
\text { у III етапі }\end{array}$ \\
\hline $2011-2012$ & 15 & 4 \\
\hline $2012-2013$ & 15 & 2 \\
\hline $2013-2014$ & 17 & 3 \\
\hline $2014-2015$ & 13 & 4 \\
\hline $2015-2016$ & 20 & 4 \\
\hline $2016-2017$ & 19 & 6 \\
\hline $2017-2018$ & 24 & \\
\hline
\end{tabular}




\section{КОМПЕТЕНТНІСНОЗОРІЕНТОВАНІПЕДАГОГІЧНІ ТЕХНОЛОГЇ ЯК ФАКТОР ЗАБЕЗПЕЧЕННЯ ЯКОСТІ ОСВІТИ У ДРОГОБИЦЬКОМУ ЛІЩЕЇ}

Таблиця 3.

Результативність участі ліцеїстів у Всеукраїнських предметних турнірах (II, III етапи)

\begin{tabular}{|c|c|}
\hline \multicolumn{1}{|c|}{} & Кількість перемог \\
\hline $2013-2014$ & 8 \\
\hline $2014-2015$ & 5 \\
\hline $2015-2016$ & 6 \\
\hline $2016-2017$ & 7 \\
\hline $2017-2018$ & 7 \\
\hline $2018-2019$ & 5 \\
\hline
\end{tabular}

Навчальна практика $\epsilon$ обов'язковою та необхідною складовою частиною навчальновиховного процесу. Вона передбачає створення умов для наближення змісту навчальних предметів до реального життя, спостереження та дослідження учнями явищ природи і процесів життєдіяльності суспільства, розширення світогляду школярів, формування в них життєво необхідних компетенцій, посилення практичної та професійно-орієнтаційної спрямованості навчально-виховного процесу. У Дрогобицькому ліцеї навчальна практика проводиться у вигляді колективних проектів, метою яких, зокрема, $є$ розвиток інтелектуальних та творчих здібностей учнів. Метод проектів передбачає використання широкого спектру проблемних, дослідницьких, пошукових методів, орієнтованих на реальний практичний результат, значущий для учня, 3 одного боку, та цілісну розробку проблем, 3 другого. Навчальні проекти виконані ліцеїстами: “Економ електроенергію!”, “Аналіз ринку банківських послуг у м. Дрогобичі”, “Екологічний стан річок міста Дрогобича", "Рідкісні дерева м. Дрогобича”, “Створення сайту Дрогобицького ліцею". Результати проектів узагальнено у науково-методичному посібнику [14].

Серед інших інтелектуальних змагань, в яких брали участь і перемагали ліцеїсти, є Intel Techno Ukraine - національний етап міжнародного конкурсу науково-технічної творчості школярів Intel ISEF, Балтійський міжнародний інженерно-технічний конкурс, Міжнародний мовно-літературний конкурс учнівської та студентської молоді ім. Т. Шевченка, конкурс “Всеукраїнський юнацький водний приз”, обласний конкурс “Славетні імена України”, конкурс юних літераторів “Весняний легіт”, конкурс творчих робіт з інформаційних технологій Національного університету “Львівська політехніка”, обласний конкурс юних програмістів “Мультимедійні проекти: сайти та презентації'.

Важливу роль у розвитку інтелектуальних та творчих здібностей ліцеїстів відіграють друковані видання ліцею:
- щомісячна газета "Ліцеїст" (видається 3 грудня 1997 р.);

- альманах учнівської творчості “Літера" (видається з 2001 р.);

- тези доповідей звітної науково-практичної конференції Дрогобицького педагогічного ліцею (видається з 2006 р.);

- Літопис Дрогобицького ліцею (видається 3 2009 p.);

- Вісник Наукового товариства Дрогобицького ліцею (видається з 2013 р.).

Описані методи та форми навчальнопошукової діяльності старшокласників у науковому товаристві забезпечують розвиток їх творчих та інтелектуальних здібностей i формують систему компетенцій, необхідну для подальшого успішного навчання у вищих навчальних закладах. Від правильної організації, оптимального поєднання традиційних i нетрадиційних методів, форм навчання та їх комбінацій залежить продуктивність навчальновиховного процесу. Запропоновані нами форми навчально-пошукової роботи сприяють розвитку самостійності, фантазії, ініціативності, творчих та інтелектуальних здібностей старшокласників, забезпечують високу активність учнів. Ефективність запропонованої методики підтверджується високою результативністю діяльності наукового товариства Дрогобицького ліцею.

Після завершення навчання на I курсі (відповідає 10 класу 33СО), ліцеїсти складають іспити з профілюючих предметів. При проведенні перевідних екзаменів необхідно передбачити можливість об'єктивного оцінювання знань учнів дискретно, за рівнями навчальних досягнень (початковий, середній, достатній, високий). В зв’язку з цим, у Дрогобицькому ліцеї, починаючи з 1997-98 н.р. складання письмового перевідного екзамену відбувається в два тури [3].

Досвід впровадження дворівневої системи проведення перевідного екзамену свідчить, що вона реалізує диференційований підхід до 


\section{КОМПЕТЕНТНІСНОЗОРІЕНТОВАНІПЕДАГОГІЧНІ ТЕХНОЛОГІЇ ЯК ФАКТОР ЗАБЕЗПЕЧЕННЯ ЯКОСТІ ОСВІТИ У ДРОГОБИЦЬКОМУ ЛІЦЁ̈}

рівневого оцінювання знань учнів, формує самооцінку та надає дитині право вибору.

Майже тридцятирічний успішний досвід функціонування ліцею у форматі профільної старшої школи дозволяє зробити висновок про результативність розробленої та впровадженої в практикуліцею системи педагогічних технологій, які формують та розвивають ключові компетентності старшокласників. Про ефективність цієї системи та якість здобутих ліцеїстами знань свідчать перші місця серед шкіл Львівської області, які здобув Дрогобицький ліцей два роки поспіль (у2017 та 2018 роках) у рейтингу, укладеному ресурсом Освіта.uа за результатами 3HO.

\section{ЛІТЕРАТУРА}

1. Hutmacher Walo. Key competencies for Europe. Report of the Symposium. Berne, Switzezland 27-30 March, 1996. Council for Cultural Co-operation (CDCC) a Secondary Education for Europe Strasburg, 1997.

2. Григорович А. Г., Заяць О. В. 3 досвіду впровадження модульно-рейтингової системи вивчення математики та інформатики. Всеукраїнська науково-практична конференція “Сучасний стан і перспективи шкільних курсів математики та інформатики у зв'язку 3 реформуванням у галузі освіти". Дрогобич, 2000. С. $48-50$.

3. Григорович А. Г., Заяць О. В., Хлопик Р. М. 3 досвіду проведення дворівневого перевідного екзаменуз фізики в Дрогобицькому педагогічному ліцеї. Всеукраїнська науково-практична конференція “Стратегічні проблеми формування змісту курсів фізики та астрономії в системі загальної середньої освіти". Львів, 2002. С.37.

4. Григорович А. Г., Заяць О. В., Заяць М. I. Методика організації і проведення звітної науковопрактичної конференції ліцеїстів. Наукова еліта як соціально-економічний фактор розвитку держав в умовах глобалізації: зб. матер. Міжнар. наук.практ. конф., (Україна, Київ, 27-28 жовт. 2010 р.) / упоряд. О.В.Биковська, О.В.Лісовий, С.О.Лихота, Л.Л.Макаренко. Вип. 1. К. : Інформаційні системи, 2010. 296 c. C.76-78.

5. Григорович А. Г., Заяць О. В., Хлопик Р. М. Методика організації та проведення літньої навчальної практики з фізики в Дрогобицькому педагогічному ліцеї. Теорія та методика навчання математики, фізики, інформатики: Збірник наукових праць. Випуск 4: В 3-х томах. Кривий Ріг: Видавничий відділ НМетАУ, 2004. Т.2: Теорія та методика навчання фізики. С. 142-145.

6. Григорович А. Г., Заяць О.В., Гладкевич
М.I. Наукове товариство як середовище розвитку інтелектуально обдарованої творчої особистості. Проектування розвитку та психологопедагогічного супроводу обдарованої особистості: матеріали VII Всеукраїнської науково-практичної конференції, 28-29 квітня 2015 року, м. Тернопіль смт. Козова. К., Інститут обдарованої дитини, 2015. С. 56-62.

7. Григорович А. Г., Заяць О. В., Гладкевич М. I. Наукове товариство як форма організації науковопошукової роботи ліцеїстів. Молодь і ринок: щомісячний науково-педагогічний журнал. №2 (85), 2012. С. 84-89.

8. Григорович А. Г., Григорович В. Г. Система залікових проектів як засіб розвитку творчих здібностей учнів при вивченні прикладного програмного забезпечення. Всеукраїнська науково-практична конференція “Сучасний стан і перспективи шкільних курсів математики та інформатики у зв'язку з реформуванням у галузі освіти". Дрогобич, 2000. С. $186-188$.

9. Григорович А., Заяць О., Гладкевич М. Формування життєвої компетентності старшокласників засобами квест-технологій. Актуальні питання гуманітарних наук: міжвузівський збірник наукових праць молодих вчених Дрогобицького державного педагогічного університету імені Івана Франка / редакториупорядники В. Ільницький, А. Душний, І. Зимомря. Дрогобич : Посвіт, 2016. Вип. 16. С. 302-308.

10. Григорович А.Г., Заяць О.В. Інноваційні технології формування ключових компетентностей у багатопрофільному ліцеї. Наука та освіта в контексті сучасних глобалізаційних процесів: збірник матеріалів всеукраїнської науково-практичної конференції (м. Київ, 01 червня 2018 року) / упоряд. Гуйда О.Г. К: ТНУ імені В. І. Вернадського, 2018. С. 42-44.

11. Закон України "Про освіту”. URL: http:// zakon.rada.gov.ua/laws/show/2145-19.

12. Заяць О. В., Григорович А. Г., Гладкевич М. I. Організація навчальної практики методом проектів у Дрогобицькому педагогічному ліцеї. Молодь i ринок: щзомісячний науковопедагогічний журнал. №3 (86), 2012. С. 48-51.

13. Григорович А.Г., Гладкевич М.І., Заяць О.В. та ін. Організаційно-методичне забезпечення діяльності шкільного наукового товариства Малої академії наук : Методичний посібник Дрогобич : Редакційно-видавничий відділ Дрогобицького державного педагогічного університету імені Івана Франка, 2016. 105 с.

14. Гладкевич М.I., Григорович А.Г., Заяць О.В. та ін. Організація навчальної практики методом проектів: методичний посібник. Дрогобич: 


\section{КОМПЕТЕНТНІСНОЗОРІЄНТОВАНІПЕДАГОПЧНІ ТЕХНОЛОПІ ЯК ФАКТОР ЗАБЕЗПЕЧЕННЯ ЯКОСТІ ОСВІТИ У ДРОГОБИЦЬКОМУ ЛІЦЁ̈}

Редакційно-видавничий відділ Дрогобицького державного педагогічного університету імені Івана Франка. 2012. 70 с.

15. Хлопик Р. М., Заяць О. В., Григорович А. Г. Методика організації та проведення семестрових індивідуальних творчих завдань з природничих дисциплін. Теорія та методика навчання математики, фізики, інформатики: Збірник наукових праць. Випуск 3: В 3-х томах. Кривий Ріг: Видавничий відділ НМетАУ, 2003. Т.2: Теорія та методика навчання фізики. С. 345-348.

\section{REFERENCES}

1. Hutmacher Walo. (1997). Key competencies for Europe. Report of the Symposium. Berne, Switzezland 27-30 March, 1996. Council for Cultural Co-operation (CDCC) a Secondary Education for Europe Strasburg. [in English].

2. Hryhorovych, A. H. \& Zaiats', O. V. (2000). Z dosvidu vprovadzhennia modulno-reitynhovoi systemy vyvchennia matematyky ta informatyky [From the experience of introducing a modular rating system for the study of mathematics and computer science]. Vseukrainska naukovo-praktychna konferentsiia "Suchasnyi stan i perspektyvy shkilnykh kursiv matematyky ta informatyky $u$ zviazku z reformuvanniam u haluzi osvity" - AllUkrainian Scientific and Practical Conference "Current state and prospects of school courses in mathematics and informatics in connection with educational reforms", Drohobych, pp. 48 - 50. [in Ukrainian].

3. Hryhorovych, A. H., Zaiats', O. V. \& Khlopyk, R. M. (2002). Z dosvidu provedennia dvorivnevoho perevidnoho ekzamenu z fizyky v Drohobytskomu pedahohichnomu litsei [From the experience of conducting a two-level examination exam in physics at the Drohobych Pedagogical Lyceum]. Vseukrainska naukovo-praktychna konferentsiia "Stratehichni problemy formuvannia zmistu kursiv fizyky ta astronomii v systemi zahalnoi serednoi osvity" - All-Ukrainian Scientific and Practical Conference "Strategic Problems of Formation of Course Contents of Physics and Astronomy in the System of General Secondary Education”, Lviv, p.37. [in Ukrainian].

4. Hryhorovych, A. H., Zaiats', O. V. \& Zaiats', M. I. (2010). Metodyka orhanizatsii i provedennia zvitnoi naukovo-praktychnoi konferentsii litseistiv [Methodology of organization and conducting of the report scientific-practical conference of lyceum students]. Naukova elita yak sotsialnoekonomichnyi faktor rozvytku derzhav $v$ umovakh hlobalizatsii: zb. mater. Mizhnar. nauk.-prakt. konf. - Scientific elite as a socio-economic factor for the development of states in the conditions of globalization: a collection of materials of the International Scientific and Practical Conference, Kyiv, pp.76-78. [in Ukrainian].

5. Hryhorovych, A. H., Zaiats', O. V. \& Khlopyk, R. M. (2004). Metodyka orhanizatsii ta provedennia litnoi navchalnoi praktyky z fizyky v Drohobytskomu pedahohichnomu litsei [Methodology of organizing and conducting summer training practice in physics at the Drohobych Pedagogical Lyceum]. Theory and methods of teaching mathematics, physics, computer science: Collection of scientific works. Issue 4, Volume 2, Kryvyi Rih, pp. 142-145. [in Ukrainian].

6. Hryhorovych, A.H., Zaiats', O.V. \& Hladkevych, M. I. (2015). Naukove tovarystvo yak seredovyshche rozvytku intelektualno obdarovanoi tvorchoi osobystosti [Scientific society as an environment for the development of intellectually gifted creative personality]. Proektuvannia rozvytku ta psykholoho-pedahohichnoho suprovodu obdarovanoi osobystosti: materialy VII Vseukrainskoi naukovo-praktychnoi konferentsii - Designing development and psychological and pedagogical support of gifted personality: Proceedings of VII All-Ukrainian Scientific-Practical Conference, Kyiv, pp. 56-62. [in Ukrainian].

7. Hryhorovych, A. H., Zaiats', O. V. \& Hladkevych, M. I. (2012). Naukove tovarystvo yak forma orhanizatsii naukovo-poshukovoi roboty litseistiv [Scientific society as a form of organization of scientific research of lyceum students]. Youth and Market: a monthly scientific and pedagogical magazine, Vol. 2 (85), pp. 84-89. [in Ukrainian].

8. Hryhorovych, A. H. \& Hryhorovych, V. H. (2000). Systema zalikovykh proektiv yak zasib rozvytku tvorchykh zdibnostei uchniv pry vyvchenni prykladnoho prohramnoho zabezpechennia [The system of graduation projects as a means of developing students' creative abilities in the study of applied software]. Vseukrainska naukovopraktychna konferentsiia "Suchasnyi stan $i$ perspektyvy shkilnykh kursiv matematyky ta informatyky u zviazku z reformuvanniam u haluzi osvity" - All-Ukrainian Scientific and Practical Conference "Current state and prospects of school courses in mathematics and informatics related to educational reform", Drohobych, pp. 186 - 188. [in Ukrainian].

9. Hryhorovych, A., Zaiats', O. \& Hladkevych, M. (2016). Formuvannia zhyttievoi kompetentnosti starshoklasnykiv zasobamy kvest-tekhnolohii [Formation of vital competency of senior pupils by means of quest-technologies]. Actual questions of the humanities: interuniversity collection of scientific works of young scientists of the Ivan Franko 


\section{КОМПЕТЕНТНІСНО ЗОРІЕНТОВАНІПЕДАГОГЧНІ ТЕХНОЛОГЇ ЯК ФАКТОР ЗАБЕЗПЕЧЕННЯ ЯКОСТІ ОСВІТИ У ДРОГОБИЦЬКОМУ ЛІЦЕЇ}

Drohobych State Pedagogical University Drohobych, Vol.16, Drohobych, pp. 302 - 308. [in Ukrainian].

10. Hryhorovych, A. \& Zaiats', O. (2018). Innovatsiini tekhnolohii formuvannia kliuchovykh kompetentnostei u bahatoprofilnomu litsei [Innovative technologies of formation of key competencies in the multi-discipline lyceum]. Science and education in the context of modern globalization processes: a Collection of Proceedings of the All-Ukrainian Scientific and Practical Conference, Kyiv, pp. $42-$ 44. [in Ukrainian].

11. The Law of Ukraine "On Education", Available at: http://zakon.rada.gov.ua/laws/show/2145-19. [in Ukrainian].

12. Zaiats', O. V., Hryhorovych, A. H. \& Hladkevych M. I. (2012). Orhanizatsiia navchalnoi praktyky metodom proektiv u Drohobytskomu pedahohichnomu litsei [Organization of practical training by projects in Drohobych Pedagogical Lyceum]. Youth and Market: a monthly scientific and pedagogical magazine, Vol. 3 (86), pp. 48 51. [in Ukrainian].
13. Hryhorovych, A., Hladkevych M. \& Zaiats', O. (2016). Orhanizatsiino-metodychne zabezpechennia diialnosti shkilnoho naukovoho tovarystva Maloi akademii nauk : Metodychnyi posibnyk [Organizational and methodological support of the activity of the school scientific society of the Small Academy of Sciences: Methodical manual]. Drohobych, 105 p. [in Ukrainian].

14. Hladkevych M., Hryhorovych, A. \& Zaiats', O. (2012). Orhanizatsiia navchalnoi praktyky metodom proektiv: metodychnyi posibnyk [Organization of educational practice by the method of projects: Methodical manual]. Drohobych, 70 p. [in Ukrainian].

15. Khlopyk, R., Zaiats', O. \& Hryhorovych, A. (2003). Metodyka orhanizatsii ta provedennia semestrovykh indyvidualnykh tvorchykh zavdan $z$ pryrodnychykh dystsyplin [Methodology of organizing and conducting semester individual creative tasks in natural sciences]. Theory and methods of teaching mathematics, physics, computer science: Collection of scientific works. Issue 3, Vol. 2, Kryvyi Rih, pp. 345 - 348. [in Ukrainian].

Стаття надійшла до редакції 20.02.2019

\section{G58089}

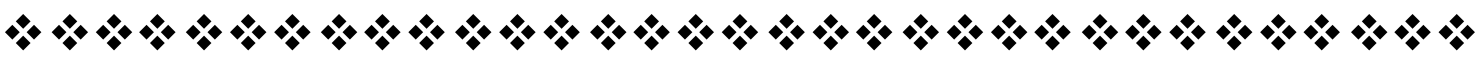

"Кожне слово вихователя повинно нести в собі добро, справедливість $і$ қрасу -в цвому суть наших повчань".

Василь Сухомлинський уқраӥнський педагог

"Начайтеся й, коли прийде час, прикладати засвоєне до справи - хіба ие не преқрасно!"

Конфуиій

давньокитайський білософ

"Розвиток й освіта жодній людині не можуть бути дані або повідомлені. Усяқий, хто бажає до них прилучитися, повинен досягти иььгго власною діяльністю, власними силами, власною наполегливістю".

Адольб Dістервег німецький педагог

"Тірирода преқрасного тақа, що чим більше на шляху до нъого трапляється перешкод, тим більше воно вабить, на зразок того найшляхетнішого $і$ найтвердішого металу, яқий чим більше треться, тим прекрасніше виблискує”.

Тригорій Сковорода уқраїнський бінособ, педагог

\section{$\% * \% * \% * \%$

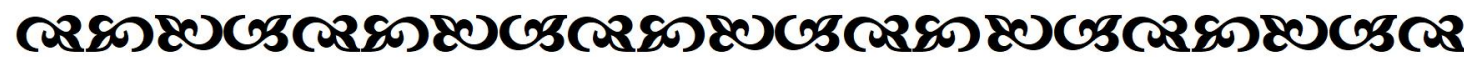

